\title{
Development and validation of an RP-HPLC method for the simultaneous determination of Escitalopram Oxalate and Clonazepam in bulk and its pharmaceutical formulations
}

\author{
*Chusena Narasimharaju Bhimanadhuni ${ }^{1}$, Devala Rao Garikapati², Pasupuleti Usha ${ }^{3}$ \\ ${ }^{1}$ Research Scholar, Department of Pharmaceutical analysis, Prist University, Thanjavur, Tamilnadu, India \\ ${ }^{2}$ Department of Pharmaceutical analysis, K.V.S.R Siddhartha College of Pharmaceutical Sciences, Vijayawada, Krishna \\ (Dt), Andhra Pradesh, India \\ ${ }^{3}$ Department of Pharmaceutical analysis, Browns college of Pharmacy, Khammam, Andhra Pradesh, India
}

\begin{abstract}
A Simple, efficient and reproducible reverse phase high performance liquid chromatographic method was developed and validated for the Simultaneous determination of Escitalopram oxalate and Clonazepam in combined dosage form. The separation was effected on a Hypersil ODS $\mathrm{C}_{18}$ column $(250 \mathrm{~mm} X 4.6 \mathrm{~mm} ; 5 \mu)$ using a mobile phase mixture of buffer and acetonitrile in a ratio of $50: 50 \mathrm{v} / \mathrm{v}$ at a flow rate of $1.0 \mathrm{ml} / \mathrm{min}$. The detection was made at $240 \mathrm{~nm}$. The retention time of Escitalopram oxalate and Clonazepam was found to be $2.840 \pm 0.007 \mathrm{~min}$ and $4.007 \pm 0.006 \mathrm{~min}$. Calibration curve was linear over the concentration range of $20-120 \mu \mathrm{g} / \mathrm{ml}$ and $1-6 \mu \mathrm{g} / \mathrm{ml}$ for Escitalopram oxalate and Clonazepam. All the analytical validation parameters were determined and found in the limit as per ICH guidelines, which indicates the validity of the method. The developed method is also found to be precise, accurate, specific, robust and rapid for the simultaneous determination of Escitalopram oxalate and Clonazepam in tablet dosage forms.
\end{abstract}

Key Words: Buffer, Acetonitrile, Escitalopram oxalate, Clonazepam, Tablets, Hypersil C18 column, RP-HPLC.

\section{INTRODUCTION}

Escitalopram oxalate (Martindale,34th edition, 2005, 292.1) [(s)-1-[3-(dimethlyamino) propyl]-1-(4flurophenyl)-1,3- dihydro isobenzofuran-5carbonitrile oxalate] is a pure s- enantiomer of the racemic, bicyclic pthalates derivatives citalopram. Escitalopram is freely soluble in methanol and dimethlysulfoxide (DMSO), sparingly soluble in water and in ethanol, slightly soluble in ethyl acetate, insoluble in heptane. It is mainly used as an antidepressant agent. Clonazepam (Merck Index, $13^{\text {th }}$ edition, 2002, 2413) [5-(o-chlorphenyl)-7-nitro$1 \mathrm{H}-1,4$-benzodiazepin-2(3H)-one] is mainly used as anticonvulsant, muscle relaxant and anxiolytic

\footnotetext{
*Corresponding Author:

Ch Narasimha Raju Bh

Department of Pharmaceutical analysis

Annabattuni Satya Narayana Pharmacy College

Burripalem Road, Tenali-522201,

Guntur(Dt), Andhra Pradesh, India

E-mail: bhchnraju@yahoo.com

Contact No.: +91-8885135987, 9849785049
}

agent. Clonazepam is slightly soluble in acetone, chloroform, acetic anhydride, hardly soluble in methanol, isopropanol, ether, almost insoluble in water. A Literature survey reveals that only a few methods based on RP-HPLC, Spectrophotometric, colorimetric methods were developed and validated for the simultaneous determination of Escitalopram oxalate and Clonazepam in combined dosage forms. Spectrophotometric determination of Escitalopram oxalate and Clonazepam using multi-component mode of analysis (Sharma et al., 2010) is available. An isocratic chiral sensitive HPLC method was developed for the separation of Escitalopram oxalate drug substance (Nagarjuna et al., 2006). HPLC assay of clonazepam in human plasma using a non-porous silica column is found (Nakamura et al., 2004). Simultaneous HPTLC determination of Escitalopram oxalate and clonazepam in combined tablets (Dhavale et al., 2008), spectrophotometric method for simultaneous Estimation of Escitalopram oxalate and clonazepam in tablet dosage forms (Kakde et al., 2009), HPLC determination of 
clonazepam in plasma using solid-phase extraction (Sallustio et al., 1994), spectrophotometric and reverse phase high-performance liquid chromatographic methods for the determination of Escitalopram oxalate and clonazepam in combined tablet dosage forms (Gandhi et al., 2008), liquid chromatography-electrospray ionisation mass spectrometric method for the determination of Escitalopram in human plasma and its applications in bioequivalence study (Singh et al., 2004), analysis of clonazepam in tablet dosage forms using small bore HPLC (Spell and Stewart, 1998), colorimetric method for the estimation of esitalopram oxalate in tablet dosage forms (Vetrichelvan et al., 2010), Automated extraction and high- performance liquid chromatographic determination of serum clonazepam (Taylor et al., 1984) are few available related works. The present investigation describes a rapid, accurate and precise RP-HPLC method for the determination of Escitalopram oxalate and Clonazepam from bulk sample and pharmaceutical combined dosage forms since this drug is being marketed in domestic and international market. The method was validated as per ICH guidelines.

\section{EXPERIMENTAL}

\section{Chromatographic Conditions}

Shimadzu made high pressure liquid chromatographic instrument provided with LC 20 AD Pump and Prominence SPD 20A UV-deuterium detector and a Hypersil ODS $\mathrm{C}_{18}$ column $(250 \mathrm{~mm} \times 4.6 \mathrm{~mm}$; $5 \mu$ ) was employed in the study. A $20 \mu \mathrm{L}$ Hamilton injection syringe was used for sample injection. Data acquisition was performed by using Spinchrome software, Shimadzu Class VP version 6.12 SPS data system (Bhimanadhuni et al, 2012). HPLC grade acetonitrile, Methonal, water were purchased from E. Merck Co; Mumbai, India, and Potassium dihydrogen phosphate,ortho phosphoric acid AR grade were purchased from SD Fine Chem Mumbai, India were used in the study.

\section{Drug Samples}

The reference samples of Escitalopram oxalate and Clonazepam was supplied by M/s Bio Leo Analytical Labs India Pvt. Ltd, Hyderabad, Andhra Pradesh, India, and branded formulation purchased from local market (Snudep plus ${ }^{\circledR}$ ).

\section{Mobile Phase}

Accurately $13.6 \mathrm{~g}$ of potassium dihydrogen phosphate was weighed and dissolved in $100 \mathrm{ml}$ of water and the volume was made up to $1000 \mathrm{ml}$ with water. $\mathrm{pH}$ was adjusted to $3.0 \pm 0.05$ using dilute ortho phosphoric acid. The solution was filtered through $0.45 \mu$ membrane filter and was degassed. A freshly prepared binary mixture of buffer: Acetonitrile in a ratio of (50:50) V/V was used as the mobile phase. Methanol was used as diluent for preparing the working solution of the drug. The mobile phase was filtered through $0.05 \mu$ membrane filter and sonicated by using Power Sonicator, model no: 405, Hwashin Technology, Korea before use (Bhimanadhuni et al; 2012). The flow rate of the mobile phase was maintained at $1.0 \mathrm{ml} / \mathrm{min}$. The column temperature was maintained at $25^{\circ} \mathrm{C}$ and the detection of the drug was carried out at $240 \mathrm{~nm}$.

\section{Stock and Working Standard Solution}

$50 \mathrm{mg}$ of Escitalopram oxalate was weighed accurately and transferred in to $50 \mathrm{ml}$ volumetric flask. The solution was sonicated and filtered through Whatman filter paper, resulting solution was diluted with the mobile phase to get a working standard solution. $2.5 \mathrm{mg}$ of Clonazepam was weighed accurately and transferred into $50 \mathrm{ml}$ volumetric flask and the solution was sonicated and filtered through Whatman filter paper, resulting solution was diluted with the mobile phase to get a working standard solution. Stock solutions of Escitalopram oxalate and Clonazepam $(1 \mathrm{mg} / 1 \mathrm{ml})$ were prepared separately using mobile phase as solvent from this standard stock solutions, mixed standard solutions of different concentrations ranging from $20-120 \mu \mathrm{g} / \mathrm{ml}$ of Escitalopram oxalate and $1-6 \mu \mathrm{g} / \mathrm{ml}$ of Clonazepam were prepared by taking suitable aliquots of working standard solution in different $10 \mathrm{ml}$ volumetric flasks and diluting up to the mark with the mobile phase. With the optimized chromatographic conditions, a steady base line was recorded. 20 micro liters of each mixed standard solution was injected 6 times and chromatograms were recorded. The retention time of Escitalopram oxalate and Clonazepam were found to be $2.840 \pm 0.007 \mathrm{~min}$ and $4.007 \pm 0.006 \mathrm{~min}$ respectively. Calibration curves were constructed by plotting the average peak areas against the respective concentrations and found be linear in the above range with the correlation coefficients $\left(\mathrm{r}^{2}\right) \quad 0.99920$ 


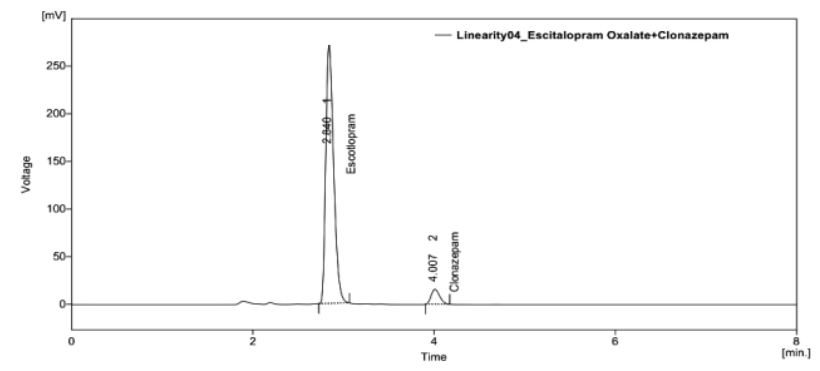

Result Table (Uncal - Linearity04_Escitalopram Oxalate+Clonazepam)

\begin{tabular}{|c|c|c|c|c|}
\hline & $\begin{array}{c}\text { Reten. Time } \\
{[\mathrm{min}]}\end{array}$ & $\begin{array}{c}\text { Area } \\
{[\mathrm{mV} . \mathrm{s}]}\end{array}$ & $\begin{array}{c}\text { Height } \\
{[\mathrm{mV}]}\end{array}$ & $\begin{array}{c}\text { Area } \\
{[\%]}\end{array}$ \\
\hline 1 & 2.840 & 1742.885 & 270.771 & 94.232 \\
\hline 2 & 4.007 & 110.566 & 15.574 & 5.768 \\
\hline & Total & 1853.451 & 286.345 & 100.000 \\
\hline
\end{tabular}

Column Performance Table (From 50\% - Linearity04_Escitalopram Oxalate+Clonazepam)

\begin{tabular}{|c|c|c|c|c|c|}
\hline & $\begin{array}{c}\text { Reten. } \\
\text { Time }\end{array}$ & $\begin{array}{c}\text { W05 } \\
{[\mathrm{min}]}\end{array}$ & $\begin{array}{c}\text { Asymmetry } \\
{[-]}\end{array}$ & $\begin{array}{c}\text { Efficiency } \\
{[\text { th.pl] }}\end{array}$ & $\begin{array}{c}\text { Resolution } \\
{[-]}\end{array}$ \\
\hline 1 & 2.840 & 0.100 & 1.650 & 4468 & - \\
\hline 2 & 4.007 & 0.103 & 1.435 & 8329 & 6.752 \\
\hline
\end{tabular}

Figure 1: Chromatogram of Escitalopram oxalate $80 \mu \mathrm{g} / \mathrm{ml}$ and Clonazepam $4 \mu \mathrm{g} / \mathrm{ml}$.

and 0.99918 for Escitalopram oxalate and clonazepam respectively. This regression equation was later used to estimate the amount of Escitalopram oxalate and clonazepam in pharmaceutical combined dosage forms. A representative chromatogram for the separation of Escitalopram oxalate and clonazepam is given in figure 1.

\section{Analysis of Tablet}

Twenty tablets (Containing both Escitalopram Oxalate and Clonazepam) were weighed and average weight was determined and finally powdered. Tablet powder equivalent to $20 \mathrm{mg}$ of Escitalopram oxalate and clonazepam was accurately weighed and transfer to $50 \mathrm{ml}$ volumetric flask.
The contents were sonicated for about $15 \mathrm{~min}$ for complete solubility of the drug after adding $25 \mathrm{ml}$ of mobile phase and the volume was made up to the mark with mobile phase. Then the mixture was filtered through a $0.45 \mu$ membrane filter. From the above solution $2.5 \mathrm{ml}$ aliquot was taken into a separate $10 \mathrm{ml}$ volumetric flask and diluted up to the volume with the mobile phase and mixed well. The above solution $(20 \mu \mathrm{L})$ was then injected Six times into the column and the peak areas were measured and the quantitation was carried out by keeping these values to the regression equation of corresponding calibration curve.

\section{RESULTS AND DISCUSSION}

The goal of this present study was aimed at developing a sensitive, precise and accurate HPLC method for the analysis of Escitalopram oxalate and clonazepam in its bulk and pharmaceutical combined dosage forms. In order to achieve optimum separation of the component peaks, mixtures of buffer with acetonitrile in different combinations were tested as mobile phase on a Hypersil $\mathrm{C}_{18}$ stationary phase. A binary mixture of buffer: acetonitrile in a proportion of 50:50 v/v was selected as the chromatographic peaks were well defined and resolved with no tailing. The retention time obtained for Escitalopram oxalate and clonazepam was found to be $2.840 \pm 0.007 \mathrm{~min}$ and $4.007 \pm 0.006 \mathrm{~min}$. Each of the samples was injected Six times and the Sample retention times were observed in all cases. The peak areas of Escitalopram oxalate and clonazepam were reproducible as indicated by low coefficient of variation. Calibration curves were constructed by plotting the average peak areas against the respective concentrations and found be linear in the above range with the correla-

Table 1: Calibration data of the proposed method.

\begin{tabular}{|c|c|c|c|c|c|c|c|c|c|c|}
\hline \multirow{2}{*}{$\begin{array}{l}\text { S1. } \\
\text { No. }\end{array}$} & \multicolumn{5}{|c|}{ Escitalopram oxalate } & \multicolumn{5}{|c|}{ Clonazepam } \\
\hline & $\begin{array}{l}\text { Concen- } \\
\text { tration } \\
(\mu \mathrm{g} / \mathrm{ml})\end{array}$ & peak area & $\begin{array}{l}\text { Correlation } \\
\text { coefficient } \\
\left(\mathbf{r}^{2}\right)\end{array}$ & $\begin{array}{l}\text { Slope } \\
\text { (m) }\end{array}$ & $\begin{array}{l}\text { Intercept } \\
\text { (b) }\end{array}$ & $\begin{array}{l}\text { Concen- } \\
\text { tration } \\
(\mu \mathrm{g} / \mathrm{ml})\end{array}$ & peak area & $\begin{array}{l}\text { Correlation } \\
\text { coefficient } \\
\left(\mathbf{r}^{2}\right) \\
\end{array}$ & Slope (m) & $\begin{array}{l}\text { Intercept } \\
\text { (b) }\end{array}$ \\
\hline 1 & 20 & 560.978 & & & & 1 & 34.850 & & & \\
\hline 2 & 40 & 911.535 & & & & 2 & 57.401 & & & \\
\hline 3 & 60 & 1370.185 & 099920 & 20.59 & 12404 & 3 & 83.692 & 0909180 & 2603 & 7025 \\
\hline 4 & 80 & 1742.885 & 0.99920 & 20.59 & 124.04 & 4 & 110.566 & 0.999188 & 26.03 & 7.025 \\
\hline 5 & 100 & 2224.455 & & & & 5 & 140.301 & & & \\
\hline 6 & 120 & 2581.977 & & & & 6 & 161.984 & & & \\
\hline
\end{tabular}


Table 2a: Accuracy data of Escitalopram oxalate (Triplicate values at $80,100,120$ percent levels).

\begin{tabular}{cccc}
\hline $\begin{array}{c}* \text { Amount } \\
\text { taken }(\boldsymbol{\mu g})\end{array}$ & $\begin{array}{c}\text { *Amount } \\
\text { found }(\boldsymbol{\mu g})\end{array}$ & $\begin{array}{c}\text { *Percent } \\
\text { recovery }\end{array}$ & $\begin{array}{c}\text { *Mean percent- } \\
\text { tage recovery }\end{array}$ \\
\hline 90 & 89.19 & 99.10 & 99.10 \\
110 & 109.68 & 99.71 & 99.71 \\
130 & 129.69 & 99.76 & 99.76 \\
\hline
\end{tabular}

*Each value is a mean of three readings

tion coefficients $\left(\mathrm{r}^{2}\right) 0.99920$ and 0.99918 for Escitalopram oxalate and clonazepam respectively. The regression curve was constructed by linear regression fitting and its mathematical expression was $\mathrm{Y}$ $=20.595 X+124.04$ and 126.03X + 7.025 (Where $Y$ gives peak area and $X$ is the concentration of the drugs of Escitalopram oxalate and clonazepam). The regression characteristics are given in table 1 . When Escitalopram oxalate and clonazepam solutions were analysed by the proposed method for finding out intra and inter-day variation, low co-efficient of variation was observed. The absence of additional peaks indicated non-interference of common excipients used in the tablets.

High recovery values obtained from the combined dosage form by the proposed method indicates the method is accurate. The drug content in tablets was quantified using the proposed analytical method are given in table $2 a$ and $2 b$.

The deliberate changes in the method have not much affected the peak tailing, Theoretical plates and the percent assay. This indicated the robustness of the method. The robustness study results are
Table 2b: Accuracy data of Clonazepam (Triplicate values at $80,100,120$ percent levels).

\begin{tabular}{cccc}
\hline $\begin{array}{c}\text { *Amount } \\
\text { taken }(\boldsymbol{\mu g})\end{array}$ & $\begin{array}{c}\text { *Amount } \\
\text { found }(\boldsymbol{\mu g})\end{array}$ & $\begin{array}{c}\text { *Percent } \\
\text { recovery }\end{array}$ & $\begin{array}{c}\text { *Mean percent- } \\
\text { tage recovery }\end{array}$ \\
\hline 4.5 & 4.49 & 99.95 & 99.95 \\
5.5 & 5.46 & 99.41 & 99.41 \\
6.5 & 6.47 & 99.59 & 99.59 \\
\hline
\end{tabular}

*Each value is a mean of three readings

presented in table 3. The lowest value of LOD and LOQ were obtained by the proposed method of Escitalopram oxalate and clonazepam indicates the sensitivity of the method. The standard solution of the drug was stable up to $24 \mathrm{hrs}$ as the difference in percent assay during the above period is within limit system suitability parameters were studied with six replicates standard solution of the drug and the calculated parameters are within the acceptance criteria. The tailing factor and the number theoretical plate are in the acceptable limits. The system suitability results are shown in table 4 .

The system precision was established by six replicate injections of the standard solution containing analytes of interest. The value of relative standard deviation of Escitalopram oxalate and clonazepam was found to be 0.261 and 0.485 within the limit, indicating the injection repeatability of the method. The method precision was established by carrying out the analysis six times using the proposed method. The relative standard deviation of Escitalopram oxalate and clonazepam was found to be 0.112 and 0.853 within the limit, indicating the injection repeatability of the method.

Table 3: Robustness Study.

\begin{tabular}{|c|c|c|c|c|c|c|}
\hline \multirow{2}{*}{ Drug name } & \multirow{2}{*}{ Variations } & \multicolumn{5}{|c|}{ Chromatographic parameters } \\
\hline & & Retention time & Area & Height & Theoretical plates & Asymmetry \\
\hline \multirow{6}{*}{$\begin{array}{l}\text { Escitalopram } \\
\text { oxalate }\end{array}$} & Change in wave length at $\pm 2 \mathrm{~nm}$ & & & & & \\
\hline & wave length at $238 \mathrm{~nm}$ & 2.837 & 2507.148 & 405.076 & 4458 & 1.75 \\
\hline & wavelength at $242 \mathrm{~nm}$ & 2.837 & 2314.536 & 373.893 & 4458 & 1.70 \\
\hline & Change in flow rate at $\pm 0.1 \mathrm{ml} / \mathrm{min}$ & & & & & \\
\hline & flow rate at $1.1 \mathrm{ml} / \mathrm{min}$ & 2.610 & 2203.232 & 380.307 & 4332 & 1.68 \\
\hline & Change in $\mathrm{pH}$ & 2.957 & 3135.473 & 488.695 & 4536 & 1.80 \\
\hline \multirow{6}{*}{ Clonazepam } & Change in wave length at $\pm 2 \mathrm{~nm}$ & & & & & \\
\hline & wave length at $238 \mathrm{~nm}$ & 3.997 & 160.023 & 24.550 & 7778 & 1.42 \\
\hline & wavelength at $242 \mathrm{~nm}$ & 3.997 & 151.185 & 22.879 & 7778 & 1.36 \\
\hline & Change in flow rate at $\pm 0.1 \mathrm{ml} / \mathrm{min}$ & & & & & \\
\hline & flow rate at $1.1 \mathrm{ml} / \mathrm{min}$ & 3.667 & 140.356 & 22.693 & 7448 & 1.455 \\
\hline & Change in $\mathrm{pH}$ & 4.163 & 190.244 & 28.640 & 8440 & 1.360 \\
\hline
\end{tabular}


Table 4: System Suitability Parameters.

\begin{tabular}{lcc}
\hline Parameters & $\begin{array}{c}\text { Escitalopram } \\
\text { oxalate }\end{array}$ & Clonazepam \\
\hline Theoretical Plates $(\mathrm{h})$ & 4782 & 8329 \\
Tailing factor $(\mathrm{T})$ & 1.650 & 1.360 \\
LOD $(\mu \mathrm{g} / \mathrm{ml})$ & 2.398 & 0.064 \\
LOQ $(\mu \mathrm{g} / \mathrm{ml})$ & 7.27 & 0.194 \\
Resolution & - & 6.865 \\
\hline
\end{tabular}

The specificity of the HPLC method was determined by the complete separation of Escitalopram oxalate and clonazepam. When it was subjected to forced degradation as per ICH guidelines which was carried out with $0.1 \mathrm{~N} \mathrm{HCL}$, Photolytic and Heat degradation at $105^{\circ} \mathrm{C}$. The method does not permit detection of degradation product for Escitalopram oxalate and clonazepam. The results of specificity data for degradation study are given in table 5 .

Hence it can be concluded that the proposed HPLC method is sensitive and reproducible for the analysis of Escitalopram oxalate and clonazepam in pharmaceutical combined dosage form with short analysis time of $8 \mathrm{~min}$.

\section{ACKNOWLEDGEMENT}

The authors are thankful to M/s Bio Leo Analytical Labs India Pvt. Ltd, Hyderabad, Andhra Pradesh, India, for providing a gift sample of Escitalopram oxalate and clonazepam and branded formulations purchased from local market, Department of pharmaceutical analysis, Prist University, Thanjayur, Tamilnadu and Principal, Dr. K.V.Ramana and Correspondent, A. Siva Kumar, A.S.N Pharmacy College, Guntur (Dt), Andhra Pradesh encouragement and providing laboratory facilities.

\section{REFERENCES}

Bhimanadhuni CN, Garikapati DR, Karamsetty S. (2012) Development and validation of RP- HPLC method for determination of Modafinil in bulk and dosage form. International Current Pharmaceutical Journal; 1(4): 77-80. [DOI]

Bhimanadhuni CN, Garikapati DR, Srinivas C. (2012) Development and validation of RP- HPLC method for determination of Duloxetine hydrochloride in bulk and dosage form. International Current Pharmaceutical Journal; 1(5): 98-102. [DOI]

Dhavale N, Gandhi S, Sabnis S, Bothara K. (2008) Simultaneous HPTLC Determination of Escitalopram Oxlate and Clonazepam in Combined Tablets.Chromatographia., 67: 478-490. [DOI]

Gandhi SV, Dhavale ND, Jadhav VY, Sabins SS. (2008) Spectrophotometric and Reversed phase High performance Liquid Chromatographic methods for simultaneous determination of Escitalopram Oxalate and Clonezepam in tablet dosage form, Journal of AOAC International, 91(1): 33-38. PMid:18376583

Kakde RB, Satone DD (2009) Spectrophotometric Method for Simultaneous Estimation of Escitalopram Oxalate and Clonazepam in Tablet Dosage Form. Indian Journal of Pharmaceutical sciences., 71(6): 702-705. [DOI] PMid:20376230 PMCid:2846482

Nagarjuna A, Raghavacharyulu KSV, Bindu HK, Mukkanti K, Suryanarayana MV. (2006) An isocratic chiral sensitive high - performance liquid chromatography method was developed for the separation of Escitalopram Oxalate drug substance. Indian drugs., 43: 746.

Nakamura M, Fukawa K, Sugiyama T, Katagiri Y.(2004) High Performance liquid chromatographic assay of clonazepam in human plasma using a non-porous silica column. Biol Pharm Bull.,27:893-5. [DOI]

Sallustio BC, Kasapidis C, Morris RG.(1994) High performance liqid chromatography determination of clonazepam in plasma using solid-phase extraction. The Drug Monit.,16:174-8. [DOI] PMid:8009566

Sharma S, Rajpurohit H, Sonwal C, Sharma P, Bhandari A. (2010) Spetrophotometric Determination of Escitalopram Oxalate and Clonazepam using Multi-Compartment Mode

Table 5: Forced Degradation.

\begin{tabular}{llccccc}
\hline Drug Name & Condition & $\begin{array}{c}\text { Time in } \\
\text { hours }\end{array}$ & $\begin{array}{c}\text { Retention } \\
\text { time (min) }\end{array}$ & Area & \% Degradation $\begin{array}{c}\text { \% of Active drug Present } \\
\text { after Degradation }\end{array}$ \\
\hline \multirow{2}{*}{$\begin{array}{l}\text { Escitalopram } \\
\text { oxalate }\end{array}$} & Acid Degradation & 24 & 2.847 & 2894.76 & 7.24 & 92.76 \\
& Photolytic Degradation & 24 & 2.843 & 1892.9 & 39.34 & 60.66 \\
& Thermal Degradation & 24 & 2.843 & 2275.33 & 27.09 & 72.91 \\
\multirow{2}{*}{ Clonazepam } & Acid Degradation & 24 & 4.007 & 158.28 & 10.48 & 89.52 \\
& Photolytic Degradation & 24 & 4.007 & 121.549 & 31.25 & 68.75 \\
& Thermal Degradation & 24 & 4.01 & 146.12 & 17.36 & 82.64 \\
\hline
\end{tabular}


of Analysis, Journal of Pharmacy Research., 3(9): 23032305.

Singh SS, sha H, Guptha S, Jain N, Sharma K, Thakkar P. (2004) Liquid chromatography electrospray ionization mass spectrometry method for the determination of Escitalopram in human plasma its application in bio equivalence study. J Chromatogr B., 811:209-15. PMid:15522722

Spell JC, Stewart JT. (1998) Analysis of clonazepam in a tablet dosage form using small bore HPLC. J Pharm Biomed Anal., 18:453-60. [DOI]

Taylor EH, Sloniewsky D, Gadsden RH.(1984) Automated extraction and high performance liquid chromatographic determination Serum clonazepam. The drug monit., 6:4747.
The Martindale, 34th edition, Pharmaceutical Press, Publication division of the royal Pharmaceutical society of great Britain,2005, 292.1(Escitalopram oxalate).

The Merck Index, $13^{\text {th }}$ edition, Merck \& Co., INC., Whitehouse station, NJ, USA, 2002, 2413 (clonazepam).

Vetrichelvan T, Arul K, Sumitra M, Umadevi B (2010) colorimetric method for estimation Escitalopram Oxalate in tablet dosage form. Indian Journal of Pharmaceutical sciences.,72 (2): 269-271. [DOI] PMid:20838541 PMCid:2929796 